\title{
Epidemiological characteristics of Leptospira spp. infection in bovine herds in Mato Grosso do Sul, Brazil*
}

\section{Caracterização soroepidemiológica da infecção por Leptospira spp. em rebanhos bovinos de corte do estado de Mato Grosso do Sul, Brasil}

\author{
Renata Ferreira dos $\operatorname{Santos}^{1}$ (D); Danila Fernanda Rodrigues Frias ${ }^{2}$ (D); Glaucenyra Cecília Pinheiro da Silva ${ }^{1}$ (D); \\ Talita Ribeiro Silva $^{1}$ (D); Nivaldo Aparecido de $\operatorname{Assis}^{1}$ (D); Carla Resende Bastos ${ }^{1}$ (D); Vanessa Felipe de Souza ${ }^{3}$ (D); \\ Luis Antonio Mathias ${ }^{1}$

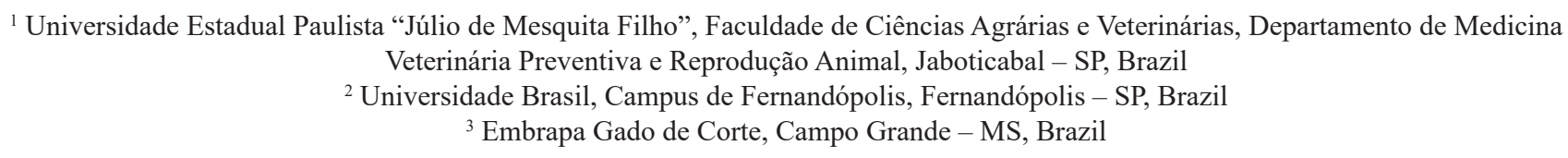

\begin{abstract}
The epidemiological characteristics of bovine leptospirosis in animals and herds in Mato Grosso do Sul were investigated to determine parameters such as disease frequency and the serovars reactant in beef cattle herds. A total of 4,629 beef cattle herds were examined against 33 Leptospira spp. serovars. The serum samples were submitted to the microscopic agglutination test (MAT) for the serological diagnosis of leptospirosis. The MAT results showed that 3,814 (82.39\%) of the 4,629 animals evaluated were seropositive for the bacterium, with serological reactions mainly to serogroup Sejroe, serovar Wolffi (36.49\%). The observed high frequency of reactive animals demonstrates the relevance of the infection. Therefore, general and specific measures should be implemented to contain and/or prevent infection of the animals in the studied region.
\end{abstract}

Keywords: Leptospirosis. Beef cattle. Microscopic Agglutination Test (MAT). Brazilian strains.

\section{RESUMO}

Foi realizado um inquérito epidemiológico da leptospirose em bovinos de rebanhos de corte do estado de Mato Grosso do Sul, de modo a determinar a frequência e as sorovariedades reagentes. Para isso, foram examinados 4.629 bovinos de corte, com uma coleção de 33 sorovariedades de Leptospira, por meio da prova de Soroaglutinação Microscópica (MAT). Dos 4.629 animais examinados, 3.814 (82,39\%) foram reagentes com reações predominates para o sorogrupo Sejroe, sorovar Wolffi (36,49\%). Assim, a alta frequência de animais reagentes encontrada justifica a implantação de medidas gerais e específicas para conter e/ou prevenir a infecção nos animais dessa região.

Palavras-chave: Leptospirose. Bovinocultura de corte. Soroaglutinação Microscópica (MAT). Estirpes brasileiras.

\footnotetext{
*This article is derived from a thesis- Santos RF. Caracterização soroepidemiológica da infecção por Leptospira spp. em rebanhos bovinos de corte do estado de Mato Grosso do Sul [tese]. Jaboticabal: Universidade Estadual Paulista; 2017 [cited 2021 Jan 4]. 62 p. Available from: https://repositorio.unesp.br/bitstream/ handle/11449/152115/santos_rf_dr_jabo_par.pdf?isAllowed=y\&sequence=3.
} 


\section{Correspondence to:}

Renata Ferreira dos Santos

Universidade Estadual Paulista "Júlio de Mesquita Filho",

Faculdade de Ciências Agrárias e Veterinárias, Departamento

de Medicina Veterinária Preventiva e Reprodução Animal

Via de Acesso Prof. Paulo Donato Castelane, s/n, Vila

Industrial

CEP: 14884-900, Jaboticabal, - SP, Brazil

e-mail: renatafdsantos@hotmail.com

Received: December 19, 2020

Approved: June 5, 2021

How to cite: Santos RF, Frias DFR, Silva GCP, Silva TR, Assis NA, Bastos CR, Souza VF, Mathias LA. Epidemiological characteristics of Leptospira spp. infection in bovine herds in Mato Grosso do Sul, Brazil. Braz J Vet Res Anim Sci. 2021;58:e180127. https://doi.org/10.11606/issn.1678-4456. bjvras.2021.180127.

\section{Introduction}

Beef cattle play a particularly important role in the Brazilian economy. Brazil has the largest commercial herd and is the largest beef exporter (Instituto Brasileiro de Geografia e Estatística, 2015) in the world. Thus, Brazil is under continuous pressure for increased productivity and profit, which can cause greater agglomerations and more favorable epidemiological conditions for maintaining and transmitting pathogens such as Leptospira spp. in the herds.

In cattle, leptospirosis is mainly linked with reproductive problems such as abortions and the birth of stillborn and/or weak animals (Oliveira et al., 2010), which causes economic losses due to dropping meat and milk production, as well as additional costs with veterinary assistance, vaccination and laboratory tests (Faine, 1993).

The Hardjo, Wolffi, Pomona, Grippotyphosa, and Icterohaemorrhagiae serovars are highlighted in the bovine species. The Hardjo and Wolffi serovars belong to the same serogroup and are described as the most frequent in the bovine species. However, in Brazil, although the Wolffi serovar is frequently detected by serology, it was never isolated in cattle.

Besides confirming the infection diagnosis, isolating Leptospira spp. in a herd with infected cattle is certainly an important step for implementing disease control programs, since it allows including native serovars in vaccines and the diagnostic microscopic agglutination test, MAT (Castro et al., 2008; Sarmento et al., 2012).

Thus, considering the cattle herd in Mato Grosso do Sul and the reproductive losses that may occur due to infection by Leptospira spp., it is important to determine the occurrence and spatial distribution of the disease in this state herds. These data should allow the adoption of prevention and control measures against the predominant serovars.

Thus, the objective of this study was to investigate the epidemiological characteristics of bovine leptospirosis in the animals and herds in one of the most important cattle ranching states, Mato Grosso do Sul, MS, in Brazil.

\section{Materials and Methods}

The study was approved by the Ethics Committee on Animal Use (CEUA), protocol 016626/14. A total of 4,629 blood serum samples were collected from male and female beef cattle (Pure-Bred Nellore, Commercial Nellore, Senepol, Caracu, and Crossbred) of different ages, from 10 herds (Table 1). The herds were chosen for convenience and extensive rearing system, in Mato Grosso do Sul. The samples analyzed in this study were collected in 2014 by EMBRAPA Gado de Corte in Campo Grande, MS, for research on leptospirosis and other diseases of interest

Table 1 - Herds (beef cattle) and their respective municipalities, mesoregions, breed, and the number of collected blood samples $\left(n^{\circ}\right)$, Mato Grosso do Sul, Brazil, 2014

\begin{tabular}{|c|c|c|c|c|c|}
\hline Herd & City & Mesoregion & Breed & Vac* & $\mathbf{n}^{\circ}$ \\
\hline 1 & Rio Brilhante & Southwest & Pure-bred Nellore /Crossbread & No & 126 \\
\hline 2 & Campo Grande & North central & Commercial Nellore/ Caracu/Senepol/ Crossbread & No & 501 \\
\hline 3 & Campo Grande & North central & Pure-bred Nellore / Crossbread & Yes & 535 \\
\hline 4 & Terenos & North central & Pure-bred Nellore / Commercial Nellore & No & 694 \\
\hline 5 & Brasilândia & East & Commercial Nellore/ Crossbread/ Senepol & No & 639 \\
\hline 6 & Dois Irmãos do Buriti & Pantanais & Pure-bred Nellore & Yes & 419 \\
\hline 7 & Miranda & Pantanais & Pure-bred Nellore & Yes & 522 \\
\hline 8 & Rio Verde de Mato Grosso & North central & Pure-bred Nellore /Commercial Nellore / Crossbread & Yes & 526 \\
\hline 9 & Camapuã & North central & Senepol/ Crossbread & No & 445 \\
\hline 10 & Miranda & Pantanais & Pure-bred Nellore & $* *$ & 222 \\
\hline Total & & & & & 4.629 \\
\hline
\end{tabular}

* Vaccination;**Some animals in the herd are vaccinated. 
in cattle herds in this region and were kindly provided for this study.

The collected samples were sent to the Virology Laboratory (EMBRAPA Gado de Corte) and stored at $-20^{\circ} \mathrm{C}$ until the serological tests. The microscopic agglutination test (MAT) was used to diagnose leptospirosis.

The blood serum samples were initially diluted in saline solution at $1 / 50$. Aliquots of $25 \mu \mathrm{L}$ were placed on flat-bottom polystyrene plates with an added equal amount of antigen from the 33 serovars of Leptospira spp. The used strains/serovars previously isolated in Brazil such as Guaicurus, Goiano, LO10, LO04, GR6, 2ACAP, Brasiliensis, 110/06, and LO14 were provided by the Leptospirosis and Brucellosis Laboratory (UNESP - Jaboticabal). The reference strains used were Andamana, Australis, Bratislava, Autumnalis, Butembo, Castellonis, Bataviae, Canicola, Whitcombi, Cynopteri, Sentot, Grippotyphosa, Hebdomadis, Copenhageni, Icterohaemorrhagiae, Javanica, Panama, Pomona, Pyrogenes, Hardjo, Patoc, Wolffi, Shermani and Tarassovi.

The serum-antigen mixture was lightly homogenized and incubated in a BOD oven at $28^{\circ} \mathrm{C}$ for 40 to $120 \mathrm{~min}$, followed by reading in dark field microscopy, with a 10x objective and eyepiece, directly from the plate wells. Samples with a titer $\geq 100$ were considered positive. The plate readings were performed by the same individual to minimize any interpretation bias. The samples reactive in the initial dilution were tested with serial dilutions from $1 / 100$ to $1 / 800$ at ratio two, following the recommendation of the World Organisation for Animal Health (2001).

To determine the frequency of occurrence, animals reactive to one or more serovars were considered seropositive. Only the serovar with the highest titer was considered as the most probable serovar while samples that presented equal titer against two or more serovars were disregarded.

The statistical analysis was performed to determine frequency distribution and calculate the confidence interval of prevalence rates per herd, using the methodology recommended by Thrusfield (2010). The difference between the frequencies of positive animals was analyzed according to the most likely source of infection serovar, and calculated based on the difference between the confidence intervals. The study was carried out using MapInfo ${ }^{\circ}$, and the density of cases was evaluated with kernel density analysis to determine hotspots.

\section{Results}

Of the 4,629 animals tested by the MAT, 3,814 (82.39\%) were seropositive for at least one of the 33 serovars used for Leptospira spp., with a titer equal or above 100 to one or more leptospiral serovar. The frequency of occurrence of herds with positive animals was $100 \%$, considering reactions to any of the serovars used as an antigen. Herd 7 in Miranda had the highest number of positive animals, 98.66\% (515/522), whereas herd 3 in Campo Grande had the lowest, 65.61\% (351/535) (Table 2).

The results showed that all eight municipalities (100\%) had animals positive to one or more of the tested leptospiral serovars (Table 3). Miranda had the highest number of positive animals, with $92.60 \%(689 / 744)$ whereas Camapuã had the lowest $71.91 \%$ (320/445) (Figure 1).

Of the 33 antigens used, reactions to Wolffi serovar were the most frequent $36.49 \%(905 / 2,480)$, followed by Shermani, $18.43 \%(457 / 2,480)$, and Hebdomadis, 8.66\% $(215 / 2,480)$. Among the nine strains isolated in Brazil, the highest occurrence of reaction was observed for Guaicurus,

Table 2 - Frequency (number and \%) cattle reactive at least to one Leptospira spp. serovar in the microscopic agglutination test (MAT) using 33 antigens, according to herd, Mato Grosso do Sul, Brazil, 2014

\begin{tabular}{crcc}
\hline \multirow{2}{*}{ Herd } & \multicolumn{2}{c}{ MAT } & \multirow{2}{*}{ Cl 95\% (\%) } \\
\cline { 2 - 3 } & Reactive* & $\mathbf{( \% )}$ & \\
\hline $\mathbf{1}$ & $91 / 126$ & 72.22 & $64.40-80.04$ \\
$\mathbf{3}$ & $430 / 501$ & 85.83 & $82.77-88.88$ \\
$\mathbf{4}$ & $351 / 535$ & 65.61 & $61.58-69.63$ \\
$\mathbf{5}$ & $531 / 694$ & 76.51 & $73.36-79.67$ \\
$\mathbf{6}$ & $559 / 639$ & 87.48 & $84.91-90.05$ \\
$\mathbf{7}$ & $365 / 419$ & 87.11 & $83.90-90.32$ \\
$\mathbf{8}$ & $515 / 522$ & 98.66 & $97.26-99.35$ \\
$\mathbf{9}$ & $478 / 526$ & 90.87 & $88.41-93.34$ \\
$\mathbf{1 0}$ & $320 / 445$ & 71.91 & $67.73-76.09$ \\
Total & $174 / 222$ & 78.38 & $72.96-83.79$ \\
\hline Positive & $3.814 / 4.629$ & 82.39 & $81.30-83.49$ \\
\hline
\end{tabular}

*Positive animals/total examined animals.

Table 3 - Frequency (number and \%) of blood serum samples from cattle reactive to at least one Leptospira spp. serovar in the microscopic agglutination test (MAT) using 33 antigens, according to the city in Mato Grosso do Sul State, Brazil, 2014

\begin{tabular}{lccc}
\hline \multirow{2}{*}{ City } & \multicolumn{2}{c}{ MAT } & \multirow{2}{*}{ CI 95\% (\%) } \\
\cline { 2 - 3 } & Reactive* & (\%) & \\
\hline Brasilândia & $559 / 639$ & 87.48 & $84.91-90.05$ \\
Camapuã & $320 / 445$ & 71.91 & $67.73-76.09$ \\
Campo Grande & $781 / 1.036$ & 75.39 & $72.76-78.01$ \\
Dois Irmãos do & $365 / 419$ & 87.11 & $83.90-90.32$ \\
Buriti & & & \\
Miranda & $689 / 744$ & 92.60 & $90.73-94.49$ \\
Rio Brilhante & $91 / 126$ & 72.22 & $64.40-80.04$ \\
Rio Verde de & $478 / 526$ & 90.87 & $88.41-93.34$ \\
M. Grosso & & & \\
Terenos & $531 / 694$ & 76.51 & $73.36-79.67$ \\
Total & $3.814 / 4.629$ & 82.39 & $81.30-83.49$ \\
\hline * Positive animals/total examined animals. & & \\
& & &
\end{tabular}




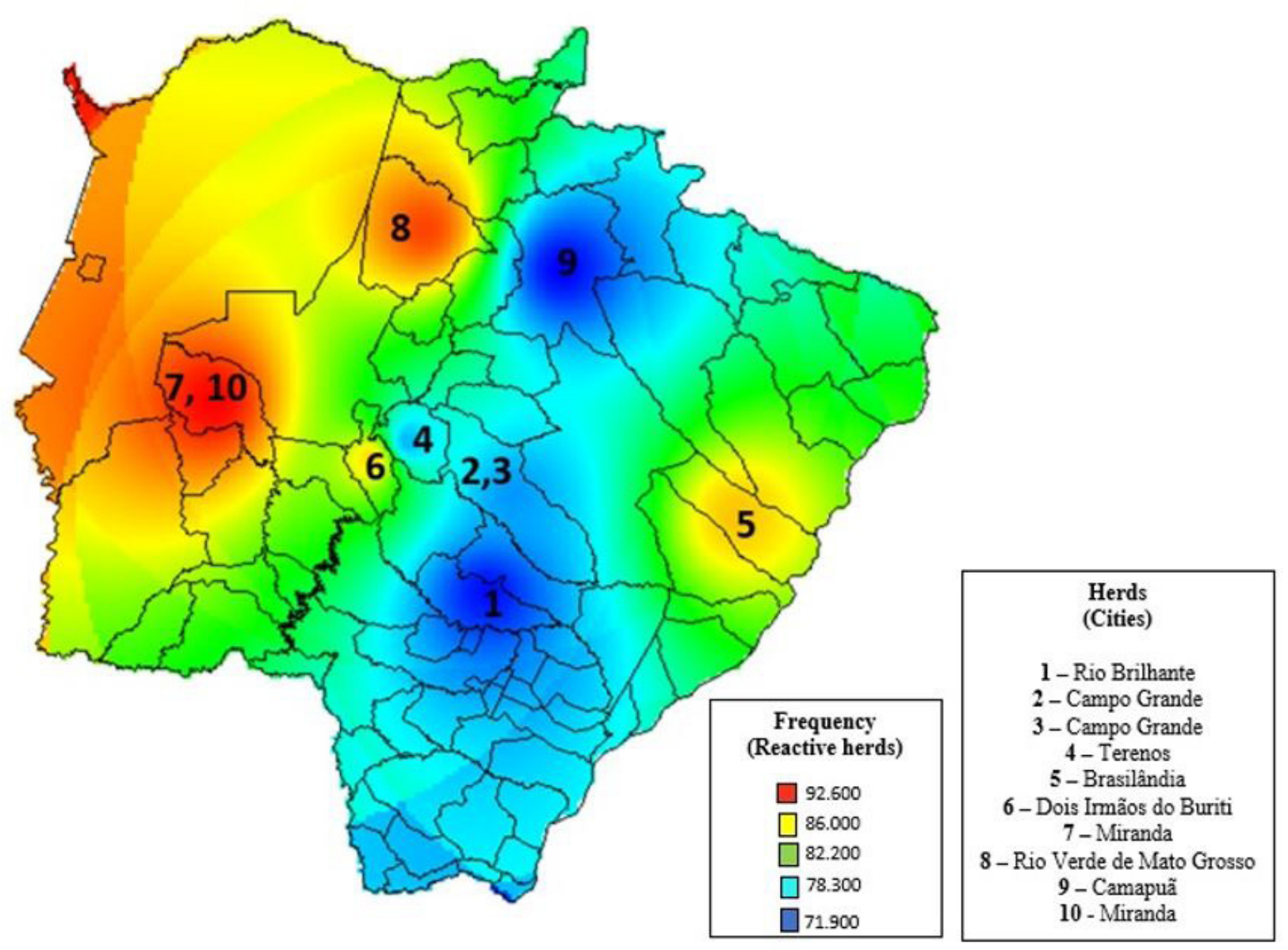

Figure 1 - Frequency (\%) of blood serum samples from cattle reactive/positive to at least one Leptospira spp. serovar in the Microscopic Agglutination Test (MAT) using 33 leptospiral serovars in cities in Mato Grosso do Sul State, Brazil, 2014.

with a frequency of $2.5 \%(62 / 2,480)$, followed by Goiano, $1.25 \%(31 / 2,480)$, and LO10 0.77\% (19/2,480).

Reaction to Wolffi serovar was found in eight of the 10 herds analyzed. It was also the most prevalent, except for one of the herds, in which it was the second-highest occurrence.

Regarding the probable serogroup causing the infection, the most frequent was Sejroe (Hardjo, Wolffi and Guaricura strains), with a frequency of $39.96 \%(991 / 2,480)$, followed by Shermani (Shermani strain), $18.43 \%(457 / 2,480)$, and Hebdomadis (Goiano and Hebdomadis strains), 9.92\% $(246 / 2,480)$.

\section{Discussion}

The frequency of serologic reactions of $82.39 \%$ (95\% CI: $81.30 \%-83.49 \%$ ) animals seropositive to Leptospira spp. in MAT and, $100 \%$ of herds reactive, was considerably high. Figueiredo et al. (2009) also reported a high prevalence, $98.8 \%(1,801 / 2,573)$, of cattle reactive to Leptospira spp. in Mato Grosso do Sul. According to Oliveira et al. (2010), seroreactivity fluctuations over time can be attributed to intrinsic and extrinsic factors that modify the epidemiological triad (etiologic agent, host, and environment).

Faine (1982) concluded that, compared to temperate regions, disease presence and dispersion are more favored in tropical and subtropical regions due to persistent bacteria in flooded environments, where they can survive for up to 180 days, depending on temperature $\left(28^{\circ} \mathrm{C}\right.$ to $\left.30^{\circ} \mathrm{C}\right)$ and $\mathrm{pH}$ (7.2 to 7.4) conditions. In Mato Grosso do Sul, the tropical climate prevails in most of the territory, characterized by rainy summers and dry winters, with average temperatures varying between $26^{\circ} \mathrm{C}$ in the Paraguay lowlands and $23^{\circ} \mathrm{C}$ in the Plateau, and approximately 1,500 $\mathrm{mm}$ rainfall annually (Borlachenco \& Gonçalves, 2017).

This high frequency of animals seropositive to Leptospira can also be attributed to the cattle breeding system adopted in Mato Grosso do Sul. The extensive rearing system widely used for the cattle herds favors the occurrence of the disease since the cattle herds are in contact with other animal species, especially wild ones, which can be important reservoirs of the disease etiological agent, favoring the permanence and spread of leptospira in the herd. 
The spatial distribution of seropositive animals per herd shows that the highest number was observed in herd seven, in Miranda, the Pantanais mesoregion. Vieira (2009) stated that the ecological and climatic conditions in the Pantanal Sul-Matogrossense are highly favorable to the occurrence of leptospirosis since the etiological agent survives longer in flooded areas and high temperatures.

The occurrence of animals positive to Wolffi (36.49\%), Shermani (18.43\%), and Hebdomadis (8.66\%) serovars was predominant in this study. In contrast, most recent serological surveys demonstrate that Hardjo serovar is the most likely to infect cattle (Coelho et al., 2014; Juliano et al., 2016; Pimenta et al., 2014).

Because the Wolffi serovar was the probable cause of infection, and there were reports of abortions in all herds, it is suggested that this serovar plays an important role as a cause of reproductive losses. While many studies report Hardjo and Wolffi as an associated occurrence, in this study the Wolffi and Shermani serovars were the predominantly associated occurrence, detected in $50 \%$ of the analyzed herds. The Wolffi predominance reinforces the importance of research to isolate this serovar since it has never been isolated from Brazilian cattle and may be important in the dissemination and maintenance of leptospirosis in Brazilian herds.

Also, it should be emphasized that the Shermani serovar has already been isolated from rodents in Brazil (Lins \& Santa Rosa, 1976), and this Brazilian isolate was obtained in Mato Grosso, a state that borders a large part of Mato Grosso do Sul territorial extension. It is noteworthy that when collecting the samples for this study, the producers/employees informed about the presence of rodents on the farms, especially capybaras (Hydrochoerus hydrochaeris), which are wild rodents, and also peccary (Tayassu tajacu). Ahmed et al. (2006) and Marvulo et al. (2002) have already isolated leptospires from the kidney of slaughtered capybaras while several studies have recorded the occurrence of capybaras seropositive to Leptospira, thus confirming the important role of this species as a bacterium reservoir.

Regarding the serovars that most likely have infected the herds in Mato Grosso do Sul, it is noteworthy that the acquired immunity is serovar-specific, and immunization protects only against homologous or antigenically similar serovars. The commercial vaccines for cattle available on the market have in their composition the antigens: Pomona, Wolff, Hardjo, Icterohaemorrhagiae, Canicola, and Grippotyphosa, which do not protect against the serovars Shermani and Hebdomadis that were highly prevalent in this and other studies on bovine leptospirosis. In addition to vaccination, Castro et al. (2008) also pointed out that the serovars Shermani, Hebdomadis, and Autumnalis are often not present in routine tests and, although they may be infecting herds, they are not being detected.

Prophylactic measures should be adopted to reduce the prevalence of infection by serovars present the population since the etiologic agent is responsible for low reproductive performance caused by infertility, abortions, stillbirths, premature births, and the birth of weak calves, among others, which consequently represent economic losses for beef cattle.

In general, the high prevalence of leptospirosis in animals and herds is emphasized, requiring the adoption of general and specific measures for preventing and controlling this disease, to improve the animal production indicators of the beef herds in the region.

\section{Conclusions}

The high frequency of reactive animals shows that infection with Leptospira spp. is occurring in herds studied in Mato Grosso do Sul, demonstrating the relevance of infection by the etiological agent. The animals were reactive to different serovars, with Wolffi serovar the most likely to infect the animals of the herds in Mato Grosso do Sul. Special attention should be paid to the Guaicurus serovar due to its significant occurrence in the analyzed herds. Thus, we suggest that it be inserted in the antigen collection when animals from the region are analyzed by the microscopic agglutination test.

\section{Conflict of Interest}

The authors declare no conflicts of interest.

\section{Ethics Statement}

Protocol 016626/14 Ethics Committee on Animal Use (CEUA) - Universidade Estadual Paulista "Júlio de Mesquita Filho", Jaboticabal.

\section{References}

Ahmed N, Devi SM, Valverde M, Vijayachari P, Machang'u RS, Ellis WA, Hartskeerl RA. Multilocus sequence typing method for identification and genotypic classification of pathogenic Leptospira species. Ann Clin Microbiol Antimicrob. 2006;5:28. http://dx.doi.org/10.1186/14760711-5-28. PMid:17121682. 
Borlachenco NGC, Gonçalves AB. Expansão agrícola: elaboração de indicadores de sustentabilidade nas cadeias produtivas de Mato Grosso do Sul. Interações. 2017;18(1):11928. http://dx.doi.org/10.20435/1984-042X-2017-v.18-n.1(09).

Castro V, Azevedo SS, Gotti TB, Batista CSA, Gentili J, Moraes ZM, Souza GO, Vasconcellos SA, Genovez ME. Soroprevalência da leptospirose em fêmeas bovinas em idade reprodutiva no estado de São Paulo, Brasil. Arq Inst Biol. 2008;75(1):3-11.

Coelho ELM, Chaves NP, Sá JC, Melo SA, Silva ALA. Prevalência de leptospirose em fêmeas bovinas abatidas em frigoríficos no município de São Luís, MA. Rev Bras Med Vet. 2014;36(2):111-5.

Faine S. Leptospira and leptospirosis., Boca Raton, Florida: CRC Press; 1993.

Faine S. Guidelines for the control of leptospirosis. 2nd ed. Geneve: World Health Organization; 1982.

Figueiredo AO, Pellegrin AO, Gonçalves VSP, Freitas EB, Monteiro LARC, Oliveira JM, Osório ALAR. Prevalência e fatores de risco para a leptospirose em bovinos de Mato Grosso do Sul. Pesq Vet Bras. 2009;29(5):375-81. http:// dx.doi.org/10.1590/S0100-736X2009000500003.

Instituto Brasileiro de Geografia e Estatística [Internet]. Pesquisa da Pecuária Municipal. Rio de Janeiro: IBGE; 2015 [cited 2016 Aug 20]. Available from: https://sidra. ibge.gov.br/pesquisa/ppm/tabelas/brasil/2015.

Juliano RS, Fioravanti MCS, Jayme VS, Silva LAF, Sereno JRB, Costa GL, Abud LJ, Maggioli MF. Ocorrência de anticorpos anti-Brucella abortus e anti-Leptospira interrogans em bovinos da raça Curraleiro Pé Duro. AICA. 2016;7:16-23.

Lins ZC, Santa Rosa CA. Investigações epidemiológicas preliminares sobre leptospiroses em Humboldt, Aripuanã, Mato Grosso. Acta Amaz. 1976;6(4):46-53. http://dx.doi. org/10.1590/1809-43921976064s049.

Marvulo MFV, Paula CD, Ferreira PM, Morais ZM, Delbem $\mathrm{ACB}$, Fávero ACM, Miraglia F, Castro V, Genovez ME,
Ferraz K, Verdade LM, Felippe PAN, Ferraz E, Penteado M, Ferreira JS No, Ferreira F, Vasconcellos SA. Detection of Leptospira in two free living populations of capybaras (Hydrochaeris hydrochaeris) from São Paulo State, Brazil. In: Proceedings of the 3rd Scientific Meeting; 2002; Bridgetown. Bridgetown: International Leptospirosis Society, 2002.

Oliveira FCS, Azevedo SS, Pinheiro SR, Batista CSA, Moraes ZM, Souza GO, Gonçales AP, Vasconcellos SA. Fatores de risco para a leptospirose em fêmeas bovinas em idade reprodutiva no estado da Bahia, Nordeste do Brasil. Pesq Vet Bras. 2010;30(5):398-402. http://dx.doi.org/10.1590/ S0100-736X2010000500004.

Pimenta CLRM, Castro V, Clementino IJ, Alves CJ, Fernandes LG, Brasil AWL, Santos CSAB, Azevedo SS. Leptospirose bovina no estado da Paraíba: prevalência e fatores de risco associados à ocorrência de propriedades positivas. Pesq Vet Bras. 2014;34(4):332-6. http://dx.doi.org/10.1590/S0100736X2014000400006.

Sarmento AMC, Azevedo SS, Morais ZM, Souza GO, Oliveira FCS, Gonçales AP, Miraglia F, Vasconcellos SA. Emprego de estirpes Leptospira spp. isoladas no Brasil na microtécnica de soroaglutinação microscópica aplicada ao diagnóstico da leptospirose em rebanhos bovinos de oito estados brasileiros. Pesq Vet Bras. 2012;32(7):601-6. http:// dx.doi.org/10.1590/S0100-736X2012000700003.

Thrusfield M. Veterinary epidemiology. 3rd ed. Oxford: Blackwell Publishing; 2010.

Vieira AS. Levantamento de Leptospira spp. em animais silvestres do Pantanal Sul-Mato-Grossense por meio de técnicas sorológicas e moleculares [tese]. Campo Grande: Universidade Federal de Mato Grosso do Sul; 2009.

World Organisation for Animal Health [Internet]. Manual of diagnostic test and vaccines for terrestrial animals. Paris: OIE; 2001 [cited 2016 Jun 26]. Available from: https://www. oie.int/en/what-we-do/standards/codes-and-manuals/ terrestrial-manual-online-access/.

Financial Support: CAPES Fundation scholarship. 